\title{
CONTRIBUTIONS TO THE BRYOPHYTE FLORA OF THE PEŠTER PLATEAU, SW SERBIA
}

\author{
B. PapP ${ }^{1}$, E. Szurdoki ${ }^{1}$, J. Pantović ${ }^{2}$ and M. Sabovljević ${ }^{2}$ \\ ${ }^{1}$ Department of Botany, Hungarian Natural History Museum \\ H-1476 Budapest, Pf. 222, Hungary; pappbea@bot.nbmus.hu \\ ${ }^{2}$ Institute of Botany and Botanical Garden, Faculty of Biology, University of Belgrade \\ Takovska 43, 11000 Belgrade, Serbia
}

\begin{abstract}
211 bryophytes ( 37 liverworts and 174 mosses) were recently collected in the Pešter plateau (SW Serbia). Of these collections, five species (Riccia canaliculata, Scapania praetervisa, Bryum canariense, Myurella sibirica, Pseudoleskeella rupestris) were found to be new records for Serbia. Four species (Lophozia ascendens, Buxbaumia viridis, Hamatocaulis vernicosus, Myurella sibirica) are included in the Red data book of European bryophytes. An additional 19 taxa can be regarded as rare in the Balkans.
\end{abstract}

Key words: European red-listed species, liverworts, mosses, new national records, rare bryophytes, the Balkans

\section{INTRODUCTION}

Thanks to intensified field works, the exploration of the bryophyte flora of Serbia has been accelerated in the last decades. More than 100 new records were added to the national list of the bryophyte flora. While SABOVLJEVIĆ and STEVANović (1999) cited 423 moss species for Serbia, the updated checklists (SABOVLJEVIĆ et al. 2008: 555 species, and Ros et al. 2013: 575 species) exhibit significant growth in the number of taxa. Similarly, SABOVLJEVIĆ (2000) cited 81 liverwort species and Sabovljević and Natcheva (2006) and Ros et al. (2007) cited 118 and 120 liverworts, respectively. The floristical results for the country are summarised in the checklists of SE Europe and the Mediterranean for liverworts (SABOVLJEViĆ and NATCHEVA 2006, Ros et al. 2007) and mosses (SABOVLJEVIĆ et al. 2008, Ros et al. 2013). Some additional bryophyte species records can be found in ERzberger and PAPp (2011), PANtović et al. (2014), PAPp and ERzBerger (2009), PAPP et al. (2012a, b,c, 2013a), and SABovljević et al. (2010). Although the last decade shows a generally better knowledge on the bryophyte flora of Serbia, many areas of the country remain bryologically poorly known. One of such areas is the Pešter plateau, which seemed to be a promising area from bryological point of view, due to its geological diversity and special microclimate, which is particularly harsh in the winter months. 


\section{MATERIAL AND METHODS}

Study area

Pešter plateau (alternatively Pešterska visoravan) is a highland area situated in southwestern Serbia, in the Sandžak region. The altitude varies between 1,150 and $1,492 \mathrm{~m}$, the latter figure marking the highest peak in the region named Kuljarski vrh. The plateau is located mainly in the Sjenica county, but parts are found in the Novi Pazar and Tutin counties. The plateau, surrounded by mountains named Golija (1,833 m), Hum (1,756 m), Jadovnik (1,734 m), Ozren (1,693 m), Zlatar (1,627 m), Giljeva (1,617 m), Žilindar (1,616 m), Javor (1,519 $\mathrm{m})$, Ninaja $(1,462 \mathrm{~m})$ and Jarut $(1,428 \mathrm{~m})$, covers about $50 \mathrm{~km}^{2}$ with the central highland named Peštersko polje. The plateau itself is the highest upland in the Balkans (and Europe) and the largest one in Serbia. It is also known as "Serbian Siberia", due to its long and harsh winters, short cool summers, and strong winds. Since measurements are recorded in Serbia, the lowest temperature, $-39^{\circ} \mathrm{C}$, was measured at Karajukića bunari village on 26 January 2006, beating the previous record of $-38.4{ }^{\circ} \mathrm{C}$ measured in Sjenica in 1954 .

The plateau is rich in (mainly karstic) water resources. The Uvac, Vapa, Jablanica and Grabovica rivers flow through the plateau. The plateau and its central field were once a big lake in the geological past, and as the area gradually drained through karst ruptures, marshy remnants were left in the lowest parts, and around streams. Some of the wetlands (encompassing 3,455 ha) are included in the Ramsar list of international importance. Beside karstic geology, ultramaphic rocks and soils are also characteristic features of the area.

The main settlements were developed in the edges of the fields; the area is mainly inhabited during summer time for cattle grazing.

Pešter plateau and its surroundings are home to a number of rare and endangered plant species, although the area is not officially protected by law (SEKULIĆ and ŠINŽAR-SEKULIĆ 2010).

\section{Methods}

Our collecting trip to the investigated area, shown in Figure 1, was made at the end of May to beginning of June in 2012, and in April 2014. All the important habitat types, such as wetlands, stream valleys, gorges, forests, rock formations and grasslands were investigated, and bryophytes collected from different substrates (soil, exposed and shaded rocks, tree bark, decaying wood, etc.).

The specimens are preserved in the Herbarium of the Hungarian Natural History Museum, Budapest (BP) and the Belgrade University Herbarium (BEOU). 


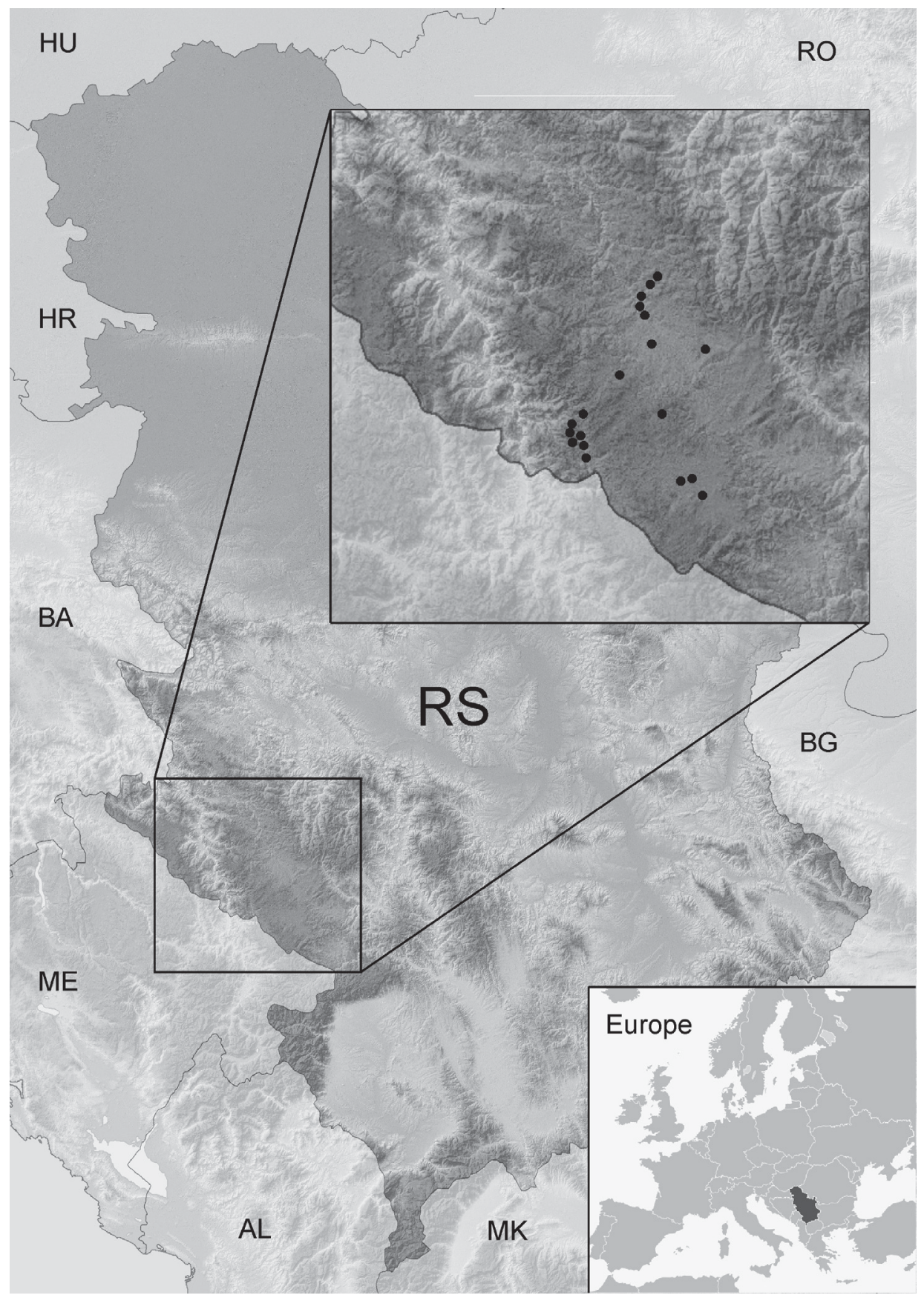

Fig. 1. Location of the study area. 
Nomenclature follows Grolle and LoNg (2000) for liverworts and Hill et al. (2006) for mosses, except for Polytrichum commune var. perigoniale, in which case KOPERSKI et al. (2000) is accepted.

\section{Site details}

1. SW Serbia, Pešter plateau, S of Karajukića bunari village, $43^{\circ} 04^{\prime} 55.2^{\prime \prime}$ N, $20^{\circ} 05^{\prime} 04.2^{\prime \prime}$ E, 1,170 $\mathrm{m}, 30.05 .2012$.

2. SW Serbia, Pešter plateau, $S$ of Karajukića bunari at Altunin bunar village towards Suvi do, limestone rocks in the pasture at Boroštica, $43^{\circ} 03^{\prime} 44.2^{\prime \prime} \mathrm{N}, 20^{\circ} 07^{\prime} 10.9^{\prime \prime} \mathrm{E}, 1,175 \mathrm{~m}, 30.05 .2012$.

3. SW Serbia, Pešter plateau, E of Karajukića bunari village, pasture along a stream, $43^{\circ} 05^{\prime} 04.1^{\prime \prime}$ $\mathrm{N}, 20^{\circ} 06^{\prime} 01.2$ ” E, $1,160 \mathrm{~m}, 30.05 .2012$.

4. SW Serbia, Pešter plateau, from Karajukića bunari village to Sjenica town between Cetanoviće and Dujke, dolina along the road, $43^{\circ} 10^{\prime} 34.1^{\prime \prime} \mathrm{N}, 20^{\circ} 02^{\prime} 33.2^{\prime \prime} \mathrm{E}, 1,270 \mathrm{~m}, 30.05 .2012$.

5. SW Serbia, Pešter plateau, from Sjenica town to Crvsko village, between Bare and Goševo, serpentine bedrock, $43^{\circ} 08^{\prime} 20.9^{\prime \prime} \mathrm{N}, 19^{\circ} 53^{\prime} 22.4^{\prime \prime}$ E, 1,110 m, 31.05.2012.

6. SW Serbia, Pešter plateau, at Crvsko village, limestone rocks in pasture, $43^{\circ} 06^{\prime} 53.3^{\prime \prime} \mathrm{N}, 19^{\circ} 54^{\prime}$ 07.2" E, $1,140 \mathrm{~m}, 31.05 .2012$.

7. SW Serbia, Pešter plateau, at Goševo village, Cerasus avium tree, $43^{\circ} 07^{\prime} 44.5^{\prime \prime}$ N, 19 53’ 51.9” E, $1,160 \mathrm{~m}, 31.05 .2012$.

8. SW Serbia, Pešter plateau, between Goševo at Bare villages, Piceo-Abietetum, $43^{\circ} 08^{\prime} 08.3^{\prime \prime} \mathrm{N}$, $19^{\circ} 52^{\prime} 52.8^{\prime \prime} \mathrm{E}, 1,165 \mathrm{~m}, 31.05 .2012$.

9. SW Serbia, Pešter plateau, near Bare village, acidic soil at roadside, $43^{\circ} 09^{\prime} 06.7^{\prime \prime} \mathrm{N}, 19^{\circ} 52^{\prime} 20.9^{\prime \prime}$ E, $1,400 \mathrm{~m}, 31.05 .2012$.

10. SW Serbia, Pešter plateau, from Sjenica to Bare village, near Bare, limestone rock and PiceoAbietetum along a stream, $43^{\circ} 10^{\prime} 09.5^{\prime \prime} \mathrm{N}, 19^{\circ} 53^{\prime} 42.0^{\prime \prime} \mathrm{E}, 1,290 \mathrm{~m}, 01.06 .2012$.

11. SW Serbia, Pešter plateau, near Bare, Piceo-Abietetum, $43^{\circ} 08^{\prime} 36.8^{\prime \prime} \mathrm{N}, 19^{\circ} 52^{\prime} 20.8^{\prime \prime} \mathrm{E}, 1,300 \mathrm{~m}$, 01.06.2012.

12. SW Serbia, Pešter plateau, from Bare to Sjenica, serpentine rocks at the roadside, $43^{\circ} 16^{\prime} 14.6^{\prime \prime}$ N, 2001'08.8” E, $1,380 \mathrm{~m}, 01.06 .2012$.

13. SW Serbia, Pešter plateau, at Sjenica ski center, limestone rocks in a dolina, $43^{\circ} 13^{\prime} 37.4^{\prime \prime} \mathrm{N}, 19^{\circ}$ 57’ 40.0” E, 1,230 m, 01.06.2012.

14. SW Serbia, Pešter plateau, along the road from Sjenica to Novi Pazar at Kneževac village, $43^{\circ}$ $15^{\prime} 52.9^{\prime \prime} \mathrm{N}, 20^{\circ} 07^{\prime} 20.2^{\prime \prime} \mathrm{E}, 1,065 \mathrm{~m}, 02.06 .2012$ and 20.04.2014.

15. SW Serbia, Pešter plateau, along the road from Sjenica to Ivanjica, Uvac Reserve, at a lakeshore, $43^{\circ} 19^{\prime} 33.0^{\prime \prime} \mathrm{N}, 20^{\circ} 00^{\prime} 13.5^{\prime \prime} \mathrm{E}, 1,000 \mathrm{~m}, 02.06 .2012$.

16. SW Serbia, Pešter plateau, along the road from Sjenica to Ivanjica, after Uvac Reserve at the

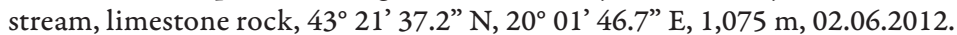

17. SW Serbia, Pešter plateau, along the road from Sjenica to Ivanjica, after Uvac Reserve at a spring, Caricetum, $43^{\circ} 21^{\prime} 01.8^{\prime \prime} \mathrm{N}, 20^{\circ} 01^{\prime} 0.7^{\prime \prime} \mathrm{E}, 1,040 \mathrm{~m}, 02.06 .2012$.

18. SW Serbia, Pešter plateau, along the road from Sjenica to Ivanjica, Uvac Reserve, under the lake, $43^{\circ} 19^{\prime} 11.5^{\prime \prime} \mathrm{N}, 20^{\circ} 00^{\prime} 08.8^{\prime \prime} \mathrm{E}, 1,000 \mathrm{~m}, 02.06 .2012$.

19. SW Serbia, Pešter plateau, along the road from Sjenica to Ivanjica, Uvac Reserve, Uvac river near Sjenica, $43^{\circ} 18^{\prime} 49.1^{\prime \prime} \mathrm{N}, 20^{\circ} 00^{\prime} 24.9^{\prime \prime} \mathrm{E}, 1,005 \mathrm{~m}, 02.06 .2012$. 


\section{RESULTS AND DISCUSSION}

Altogether 211 bryophytes (37 liverworts and 174 mosses) were collected in the Pešter plateau. The numerals following the species names refer to the collection sites described above.

\section{Hepaticae}

Aneura pinguis (L.) Dumort. - 14: in Caricetum

Apometzgeria pubescens (Schrank) Kuwah. - 10: limestone rock

Barbilophozia barbata (Schreb.) Loeske - 13: limestone rock

Cephaloziella divaricata (Sm.) Schiffn. - 1: limestone rock; 5: serpentine grassland

Conocephalum salebrosum Szweyk., Buczkowska et Odrzykoski - 5: wet meadow at the stream; 10: at a spring

Frullania dilatata (L.) Dumort. - 5: serpentine grassland and bark of Salix caprea; 19: Salix bark

Jungermannia leiantha Grolle - 11: decaying wood

Leiocolea collaris (Nees) Schljakov - 10: limestone rock

Lejeunea cavifolia (Ehrh.) Lindb. - 5: serpentine rock

Lepidozia reptans (L.) Dumort. - 11: decaying wood

Lophocolea bidentata (L.) Dumort. - 9: acidic soil at roadside

Lophocolea heterophylla (Schrad.) Dumort. - 1: in Caricetum; 10, 11: decaying wood

Lophocolea minor Nees - 5: serpentine rock; 9: acidic soil at roadside

Lophozia ascendens (Warnst.) R. M. Schust. - 11: decaying wood

Lophozia excisa (Dicks.) Dumort. - 12: serpentine rock

Lophozia incisa (Schrad.) Dumort. - 9: acidic soil at roadside

Lophozia obtusa (Lindb.) A. Evans - 9: acidic soil at roadside; 10: limestone rock; 12: serpentine rock

Marchantia polymorpha L. subsp. polymorpha - 14: in Caricetum

Metzgeria furcata (L.) Dumort. - 5: serpentine rock; 10: limestone rock

Nowellia curvifolia (Dicks.) Mitt. - 10, 11: decaying wood

Pellia endiviifolia (Dicks.) Dumort. - 5: wet meadow at the stream; 10: at a spring

Plagiochila asplenioides (L. emend. Taylor) Dumort. - 10: along a stream

Plagiochila porelloides (Torrey ex Nees) Lindenb. - 5, 12: serpentine rock; 9: acidic soil at roadside; 10: limestone rock

Porella cordaeana (Huebener) Moore - 5: serpentine rock; 10: limestone rock; 11: decaying wood Preissia quadrata (Scop.) Nees - 10, 13: limestone rock

Ptilidium pulcherrimum (Weber) Vain. - 8, 10, 11: decaying wood

Radula complanata (L.) Dumort. - 2, 10: limestone rock; 5: serpentine rock and bark of Salix caprea; 8: bark of Populus tremula

Reboulia hemisphaerica (L.) Raddi - 2, 13, 18: soil among limestone rocks

Riccardia multifida (L.) Gray - 10: along a stream

Riccia canaliculata Hoffm. - 3: at the stream (conf. S. Ştefãnuț) (PAPP et al. 2014b)

Riccia ciliifera Link ex Lindenb. - 3: in pasture

Riccia glauca L. - 3: in pasture; 15: soil at a lake

Riccia sorocarpa Bisch. var. sorocarpa - 3: in pasture

Riccia sorocarpa Bisch. var. heegii Schiffn. - 13: soil among limestone rocks

Scapania aspera M. Bernet et Bernet - 10: limestone rock 
Scapania calcicola (Arnell et J. Perss.) Ingham - 10: limestone rock

Scapania praetervisa Meyl. - 12: serpentine rock (conf. S. Ştefãnuț) (PAPP et al. 2014b)

\section{Musci}

Abietinella abietina (Hedw.) M. Fleisch. - 1: in pasture; 2: limestone rock; 5: serpentine grassland Amblystegium confervoides (Brid.) Schimp. - 5: serpentine rock

Amblystegium serpens (Hedw.) Schimp. - 1: in pasture and Caricetum; 5: serpentine rock; 10: decaying wood

Amphidium mougeotii (Schimp.) Schimp. - 5: serpentine rock

Anomodon attenuatus (Hedw.) Huebener - 5: serpentine rock and bark of Salix caprea

Anomodon viticulosus (Hedw.) Hook. et Taylor - 2, 10, 13: limestone rock; 5: serpentine rock

Atrichum undulatum (Hedw.) P. Beauv. - 1: in pasture; 5: wet meadow at the stream

Aulacomnium palustre (Hedw.) Schwägr. - 1: in Caricetum; 3: in pasture

Bartramia halleriana Hedw. - 12: serpentine rock

Bartramia ithyphylla Brid. - 12: serpentine rock

Bartramia pomiformis Hedw. - 5: serpentine rock

Brachytheciastrum velutinum (Hedw.) Ignatov et Huttunen - 8, 11: decaying wood; 9: acidic soil at roadside; 10: sandstone rock

Brachythecium albicans (Hedw.) Schimp. - 1: in pasture; 2: limestone rock

Brachythecium glareosum (Spruce) Schimp. - 2: limestone rock

Brachythecium mildeanum (Schimp.) Schimp. - 3: in pasture

Brachythecium rivulare Schimp. - 5: wet meadow at the stream; 16: limestone rock at the stream

Brachythecium rutabulum (Hedw.) Schimp. - 1: in Caricetum; 5: wet meadow at the stream and serpentine rock; 17: at a spring

Brachythecium tommasinii (Sendtn. ex Boulay) Ignatov et Huttunen - 13: limestone rock

Bryoerythrophyllum recurvirostrum (Hedw.) P. C. Chen - 2, 4: limestone rock; 5: serpentine grassland; 19: Salix bark

Bryum alpinum Huds. ex With. - 1, 3: in pasture; 5: serpentine grassland

Bryum archangelicum Bruch et Schimp. - 1: in a pasture (det. W. Schröder) and Caricetum

Bryum argenteum Hedw. - 1: in pasture; 4: limestone rock; 5: serpentine grassland

Bryum caespiticium Hedw. - 1: in pasture; 2, 13: limestone rock; 5: serpentine grassland

Bryum canariense Brid. - 1: in pasture (conf. W. Schröder) (PAPP et al. 2014c)

Bryum capillare Hedw. - 11: soil

Bryum elegans Nees - 1: in pasture (conf. W. Schröder); 2: limestone rock

Bryum gemmiferum R. Wilczek et Demaret - 1: in pasture

Bryum moravicum Podp. - 2, 13: limestone rock; 5: serpentine grassland; 8: decaying wood; 19: limestone rock at the river

Bryum pseudotriquetrum (Hedw.) P. Gaertn., B. Mey. et Scherb. - 1, 14: in Caricetum; 3: in pasture; 5: wet meadow at the stream; 10: along a stream; 17: at a spring

Bryum uliginosum (Brid.) Bruch et Schimp. - 13: limestone rock (det. W. Schröder)

Buxbaumia viridis (Moug. ex Lam. et DC.) Brid. ex Moug. et Nestl. - 10, 11: decaying wood

Calliergon giganteum (Schimp.) Kindb. - 14: in Caricetum

Calliergonella cuspidata (Hedw.) Loeske - 1, 14: in Caricetum; 3: in pasture; 5: wet meadow at the stream; 10, 17: at a spring; 16: limestone rock at the stream

Campylium protensum (Brid.) Kindb. - 10: limestone rock

Campylophyllum calcareum (Crundw. et Nyholm) Hedenäs - 5: serpentine grassland

Ceratodon purpureus (Hedw.) Brid. - 1: in Caricetum and soil among limestone rocks; 5: wet meadow at the stream and serpentine grassland 
Cinclidotus fontinaloides (Hedw.) P. Beauv. - 19: limestone rock at the river Cinclidotus riparius (Host ex Brid.) Arn. - 19: limestone rock at the river Cirriphyllum piliferum (Hedw.) Grout - 9: acidic soil at roadside

Climacium dendroides (Hedw.) F. Weber et D. Mohr - 1: in Caricetum; 5: wet meadow at the stream Cratoneuron filicinum (Hedw.) Spruce - 4, 10: limestone rock; 5: wet meadow at the stream and serpentine rock; 10: along a stream; 16, 19: limestone rock at the stream; 17: at a spring

Ctenidium molluscum (Hedw.) Mitt. - 10, 13: limestone rock

Dicranella schreberiana (Hedw.) Dixon - 3: in pasture

Dicranum bonjeanii De Not. - 1 : in pasture

Dicranum polysetum Sw. ex anon. - 8: soil

Dicranum scoparium Hedw. - 8: soil; 10, 11: decaying wood; 12: serpentine rock

Dicranum tauricum Sapjegin - 8, 10, 11: decaying wood

Didymodon fallax (Hedw.) R. H. Zander - 9: acidic soil at roadside

Didymodon ferrugineus (Besch.) M. O. Hill - 5: serpentine grassland

Didymodon rigidulus Hedw. -2 , 10, 13: limestone rock; 16: limestone rock at the stream

Didymodon vinealis (Brid.) R. H. Zander - 14: in dry grassland

Distichium capillaceum (Hedw.) Bruch et Schimp. - 10, 13: limestone rock

Ditrichum flexicaule (Schwägr.) Hampe - 3, 6, 13: limestone rock; 10: sandstone and serpentine rocks; 16 : limestone rock at the stream

Ditrichum gracile (Mitt.) Kuntze - 2, 10, 13: limestone rock

Ditrichum pusillum (Hedw.) Hampe - 1: in pasture

Drepanocladus aduncus (Hedw.) Warnst. - 1, 14: in Caricetum; 15: soil at a lake

Drepanocladus polygamus (Schimp.) Hedenäs - 3: in pasture

Encalypta ciliata Hedw. - 12: serpentine rock

Encalypta streptocarpa Hedw. - 2, 10, 13: limestone rock; 10: sandstone rock

Encalypta vulgaris Hedw. - 2, 13: limestone rock; 5: serpentine grassland; 10: serpentine rock

Entosthodon fascicularis (Hedw.) Müll. Hal. - 14: on the soil along the road

Eurhynchiastrum pulchellum (Hedw.) Ignatov et Huttunen var. pulchellum - 12: serpentine rock

Eurhynchiastrum pulchellum (Hedw.) Ignatov et Huttunen var. diversifolium (Schimp.) Ochyra et Żarnowiec - 2: limestone rock

Eurhynchium angustirete (Broth.) T. J. Kop. - 10: along a stream; 11: soil

Fissidens adianthoides Hedw. - 3: in pasture

Fissidens dubius P. Beauv. - 10: limestone rock and at a spring

Fissidens taxifolius Hedw. - 5: serpentine rock; 9: acidic soil at roadside; 10: limestone rock

Fontinalis antipyretica Hedw. - 16, 19: limestone rock at the stream

Funaria hygrometrica Hedw. - 1: in Caricetum

Grimmia laevigata (Brid.) Brid. - 5: serpentine grassland

Grimmia ovalis (Hedw.) Lindb. - 5: serpentine grassland

Grimmia pulvinata (Hedw.) Sm. - 4, 6, 13: limestone rock; 5: serpentine grassland

Gymnostomum calcareum Nees et Hornsch. - 10: limestone rock

Hamatocaulis vernicosus (Mitt.) Hedenäs - 14: in Caricetum

Hedwigia ciliata (Hedw.) P. Beauv. var. leucophaea Bruch et Schimp. - 5: serpentine grassland

Herzogiella seligeri (Brid.) Z. Iwats. - 10, 11: decaying wood

Homalothecium sericeum (Hedw.) Schimp. - 2, 6, 10, 13: limestone rock; 5: serpentine rock and bark of Salix caprea; 10: serpentine rock; 16: limestone rock at the stream

Homomallium incurvatum (Brid.) Loeske - 5: serpentine rock

Hygrohypnum luridum (Hedw.) Jenn. - 5: serpentine rock; 16: limestone rock at the stream

Hylocomium splendens (Hedw.) Schimp. - 8: soil; 10: limestone rock 
Hypnum cupressiforme Hedw. var. cupressiforme - 5: serpentine rock and bark of Salix caprea; 8: soil; 11: decaying wood

Hypnum cupressiforme Hedw. var. lacunosum Brid. - 5: serpentine grassland; 9: acidic soil at roadside Isopterygiopsis pulchella (Hedw.) Z. Iwats. - 10: limestone rock

Leptodictyum riparium (Hedw.) Warnst. - 14: in Caricetum; 19: limestone rock at the river

Leskea polycarpa Hedw. - 19: limestone rock at the river and Salix bark

Leucodon sciuroides (Hedw.) Schwägr. - 5: serpentine grassland and bark of Salix caprea

Mnium lycopodioides Schwägr. - 5: serpentine rock

Mnium marginatum (Dicks.) P. Beauv. - 5: serpentine rock

Mnium stellare Hedw. - 2: limestone rock; 5: serpentine rock

Myurella sibirica (Müll. Hal.) Reimers - 13: limestone rock (conf. L. Meinunger) (PAPP et al. 2014a)

Neckera complanata (Hedw.) Huebener - 5: serpentine rock; 10: limestone rock

Neckera crispa Hedw. - 10: limestone rock

Neckera menziesii Drumm. - 5: serpentine rock; 10, 13: limestone rock

Orthotrichum affine Schrad. ex Brid. - 5: bark of Salix caprea; 7: bark of Cerasus avium; 8: bark of Populus tremula; 19: Salix bark

Orthotrichum anomalum Hedw. - 1, 2, 6, 13: limestone rock; 16, 19: limestone rock at the stream Orthotrichum cupulatum Hoffm. ex Brid. var. cupulatum - 1, 2, 13: limestone rock; 16: limestone rock at the stream

Orthotrichum cupulatum Hoffm. ex Brid. var. riparium Huebener - 19: limestone rock at the river Orthotrichum lyellii Hook. et Taylor - 5: bark of Salix caprea

Orthotrichum obtusifolium Brid. - 8: bark of Populus tremula; 19: Salix bark

Orthotrichum pallens Bruch ex Brid. - 5: bark of Salix caprea; 19: Salix bark

Orthotrichum pumilum Sw. ex anon. - 19: Salix bark

Orthotrichum rupestre Schleich. ex Schwägr. - 5: serpentine grassland

Orthotrichum speciosum Nees - 5: bark of Salix caprea; 7: bark of Cerasus avium; 8: bark of Populus tremula; 19: Salix bark

Orthotrichum stramineum Hornsch. ex Brid. - 7: bark of Cerasus avium; 19: Salix bark

Orthotrichum striatum Hedw. - 5: bark of Salix caprea; 7: bark of Cerasus avium; 8: bark of Populus tremula; 19: Salix bark

Oxyrrhynchium hians (Hedw.) Loeske - 10: at a spring; 13: limestone rock

Palustriella commutata (Hedw.) Ochyra - 5: wet meadow at the stream; 10: at a spring

Palustriella falcata (Brid.) Hedenäs - 10: at a spring

Phascum cuspidatum Hedw. - 14: in dry grassland

Philonotis fontana (Hedw.) Brid. - 3: at the stream

Philonotis seriata Mitt. - 5: wet meadow at the stream

Physcomitrium pyriforme (Hedw.) Bruch et Schimp. - 15: soil at a lake

Plagiobryum zieri (Hedw.) Lindb. - 13: limestone rock

Plagiomnium affine (Blandow ex Funck) T. J. Kop. - 1, 3: in pasture; 5: serpentine rock

Plagiomnium cuspidatum (Hedw.) T. J. Kop. - 2: limestone rock; 5: serpentine rock

Plagiomnium elatum (Bruch et Schimp.) T. J. Kop. - 5: wet meadow at the stream; 14: in Caricetum; 17: at a spring

Plagiomnium rostratum (Schrad.) T. J. Kop. -2 , 13: limestone rock; 5: serpentine rock; 10: along a stream

Plagiomnium undulatum (Hedw.) T. J. Kop. - 5: serpentine rock; 10: along a stream

Plagiopus oederianus (Sw.) H. A. Crum et L. E. Anderson - 10, 13: limestone rock

Plagiothecium cavifolium (Brid.) Z. Iwats. - 5: serpentine rock

Platyhypnidium riparioides (Hedw.) Dixon - 5: serpentine rock 
Pleuridium acuminatum Lindb. - 1, 3: in pasture

Pleurozium schreberi (Willd. ex Brid.) Mitt. - 1: in pasture; 8: soil; 9: acidic soil at roadside; 11: soil Pogonatum urnigerum (Hedw.) P. Beauv. - 9: acidic soil at roadside

Pohlia cruda (Hedw.) Lindb. - 12: serpentine rock

Poblia wablenbergii (F. Weber et D. Mohr) A. L. Andrews - 3: in pasture; 17: at a spring

Polytrichastrum alpinum (Hedw.) G. L. Sm. - 1: in pasture; 9: acidic soil at roadside; 12: serpentine rock

Polytrichum commune Hedw. var. commune - 1: in Caricetum

Polytrichum commune Hedw. var. perigoniale (Michx.) Hampe - 1: in pasture

Polytrichum juniperinum Hedw. - 1, 3: in pasture

Polytrichum piliferum Hedw. - 5: serpentine grassland

Pseudoleskeella catenulata (Brid. ex Schrad.) Kindb. - 2, 4, 10, 13: limestone rock; 16: limestone rock at the stream

Pseudoleskeella rupestris (Berggr.) Hedenäs et L. Söderstr. - 5: serpentine rock (PAPP et al. 2014b)

Pseudoscleropodium purum (Hedw.) M. Fleisch. - 10: along a stream

Pterigynandrum filiforme Hedw. - 8: decaying wood

Pylaisia polyantha (Hedw.) Schimp. - 16: limestone rock at the stream; 19: limestone rock at the stream and Salix bark

Racomitrium canescens (Hedw.) Brid. - 5: serpentine grassland

Racomitrium elongatum Ehrh. ex Frisvoll - 5: serpentine grassland; 11: soil

Rhizomnium punctatum (Hedw.) T. J. Kop. - 10: along a stream; 11: decaying wood

Rhynchostegium murale (Hedw.) Schimp. - 10: limestone rock

Rhytidiadelphus triquetrus (Hedw.) Warnst. - 8: soil; 9: acidic soil at roadside; 10: limestone rock; 12: serpentine rock

Rhytidium rugosum (Hedw.) Kindb. - 1: in pasture; 5: serpentine grassland; 6: limestone grassland Saelania glaucescens (Hedw.) Broth. - 12: serpentine rock

Sanionia uncinata (Hedw.) Loeske - 11: decaying wood

Schistidium apocarpum (Hedw.) Bruch et Schimp. - 5, 12: serpentine rock

Schistidium atrofuscum (Schimp.) Limpr. - 6, 13: limestone rock

Schistidium brunnescens Limpr. subsp. brunnescens - 2: limestone rock

Schistidium brunnescens Limpr. subsp. griseum (Nees et Hornsch.) H. H. Blom - 2, 3, 6, 13: limestone rock

Schistidium confertum (Funck) Bruch et Schimp. - 5: serpentine grassland

Schistidium crassipilum H. H. Blom - 1, 2, 6, 10: limestone rock; 16, 19: limestone rock at the stream

Schistidium flaccidum (De Not.) Ochyra - 5: serpentine grassland

Schistidium helveticum (Schkuhr) Deguchi - 5: serpentine grassland

Sciuro-hypnum populeum (Hedw.) Ignatov et Huttunen - 5: serpentine rock

Seligeria pusilla (Hedw.) Bruch et Schimp. - 10: limestone rock

Sphagnum palustre L. - 1: in pasture

Sphagnum subsecundum Nees - 1 : in pasture

Straminergon stramineum (Dicks. ex Brid.) Hedenäs - 1: in Caricetum

Syntrichia calcicola J. J. Amann - 5: serpentine grassland; 13: limestone rock

Syntrichia latifolia (Bruch ex Hartm.) Huebener - 19: Salix bark

Syntrichia montana Nees - 3: limestone rock

Syntrichia ruralis (Hedw.) F. Weber et D. Mohr - 1: in pasture; 2, 4, 6, 10: limestone rock; 5: serpentine grassland; 19: limestone rock at the river and Salix bark

Taxiphyllum wissgrillii (Garov.) Wijk et Margad. - 5: serpentine rock 
Thamnobryum alopecurum (Hedw.) Gangulee - 5: serpentine rock

Thuidium assimile (Mitt.) A. Jaeger - 5: serpentine rock

Timmia austriaca Hedw. - 10, 13: limestone rock

Tortella fragilis (Hook. et Wilson) Limpr. - 2, 3: limestone rock

Tortella inclinata (R. Hedw.) Limpr. - 3, 13: limestone rock

Tortella tortuosa (Hedw.) Limpr. - 2, 3, 6, 10, 13: limestone rock; 5: serpentine rock; 11: soil; 16: limestone rock at the stream

Tortula muralis Hedw. - 13: limestone rock

Tortula subulata Hedw. - 2: limestone rock; 5: serpentine grassland; 9: acidic soil at roadside; 10: sandstone rock; 12: serpentine rock; 16: limestone rock at the stream

Trichodon cylindricus (Hedw.) Schimp. - 1: in pasture

Warnstorfia exannulata (Schimp.) Loeske - 1: in Caricetum

Weissia condensa (Voit) Lindb. - 6: limestone rock

Weissia controversa Hedw. -5 : serpentine grassland

Five species were found to be first records for Serbia, and these were published in separate papers; Bryum canariense in PAPP et al. (2014c), Myurella sibirica (PAPP et al. 2014a), Riccia canaliculata, Scapania praetervisa and Pseudoleskeella rupestris in (PAPP et al. 2014b).

Riccia canaliculata is a species of the southern temperate zones of Europe (DÜLL 1983). In SE Europe it is known only from Greece and Romania (Ros et al. 2007). In Romania, it is included in the national red list in data-deficient (DD) category (ŞTEFĂNUȚ and GoIA 2012).

Scapania praetervisa is a rare arctic-alpine species (DÜLL 1983). Recently, it has been reported as new to Balkans, from the Republic of Macedonia (PAPP et al. 2011) and from Montenegro (PAPP et al. 2013b).

Bryum canariense is an interesting moss of austral tropical to temperate distribution (DIERSSEN 2001). It is known from all countries of SE Europe except Romania (SABOVLJEVIĆ et al. 2008). It is a threatened species; in Bulgaria it is classified as vulnerable (NATCHeVA et al. 2006) and as at low risk in Montenegro (SABOVlJEvić et al. 2004).

Myurella sibirica is a subarctic, alpine element (DÜLL 1985). In SE Europe it is known only from Slovenia and Bosnia-Herzegovina according to SABOVLJEVIĆ et al. (2008) and has been only recently reported from Montenegro (PAPP et al. 2014a). According to the Red data book of European bryophytes (ECCB 1995) it is considered as endangered in Europe. It is known only from a few countries in Europe; in Austria it is considered as potentially endangered (GRIMS 1999), and in Slovakia as endangered (KUBINSKÁ et al.2001).

Pseudoleskeella rupestris is a circumpolar, boreal, montane (SмIтн 2004) species previously treated as a variety of $P$. catenulata. This moss is newly reported for the Balkans, from Montenegro (DrAGIĆEvić et al. 2008) and Albania (PAPP et al. 2010). 


\section{Species red-listed in Europe}

Four species are included in the Red data book of European bryophytes (ECCB 1995). These are as follows.

Lophozia ascendens is a boreal, montane liverwort (DüLL 1983) living on decaying wood in constantly humid forests. It is rare (R) in Europe according to the Red data book of European bryophytes (ECCB 1995). Several vigorous populations can be found in Serbia (PAPP et al. 2009) and in some neighbouring Balkan countries, such as Croatia (PAPP et al. 2013c,d) and Montenegro (PAPP et al. 2013b, PAPp and ErzBerger 2010, PAPP et al. 2014d).

Buxbaumia viridis is a boreal, montane species (DÜLL 1984). It also thrives on well-decayed wood in humid forests. This moss is included in the Bern Convention and the European Union Habitats and Species Directives (ECCB 1995), vulnerable in Europe according to the Red data book of European bryophytes (ECCB 1995). Several extant populations are known in Serbia (PAPP et al. 2009) and in some neighbouring Balkan countries, such as Croatia (ALEgro et al. 2014, PAPP et al. 2013c,d), Montenegro (DragiĆEviĆ et al. 2011), and the Republic of Macedonia (PAPP and ERZBERGER 2012).

Hamatocaulis vernicosus is a boreal element (DüLL 1985) occurring in oligotrophic wet grasslands. It is included in the Bern Convention, the European Union Habitats and Species Directive, and as insufficiently known $(\mathrm{K})$ in Europe according to the Red data book of European bryophytes (ECCB 1995). Pešter plateau is its second locality in Serbia. It has an extant population at Vlasina lake, but at that location only a few individuals were collected, intermixed with Warnstorfia exannulata in an Eriophoretum wetland (PAPP et al. 2012d). At the Pešter plateau, uniquely, a large population, covering $c a 25 \mathrm{~m}^{2}$ as an almost clear stand was found in Caricetum. The species is very rare in the Balkans. Its only known locality in Montenegro is at Barno jezero in the Durmitor Mts, where the existence of the population was proved in 2004 (PAPP and ERZBERGER 2010). There is a recently found population in Croatia, in Plitvička jezera National Park, which is the single known really viable population of this species in that country (ALEGRO et al. 2014).

Myurella sibirica is a subarctic, alpine element (DüLL 1985) living on limestone rocks, in rock crevices in montane to high-mountain habitats. It is endangered in Europe according to the Red data book of European bryophytes (ECCB 1995). It has recently been reported for the first time from Serbia, on the basis of this record from the Pešter plateau, and from Montenegro (PAPP et al. 2014a). Previously, in SE Europe it was only known from Slovenia and Bosnia-Herzegovina, according to SABOVLJEVIĆ et al. (2008). 


\section{CONCLUSIONS}

Pešter plateau maintains high bryophyte diversity due to the various habitat types and bedrocks occurring in this upland area. From the aspect of bryophyte conservation, wetlands are the most important habitat types on the Pešter plateau, because they are rare, sporadic, and of limited size in the Balkans. The wetlands of the Pešter plateau support the existence of Sphagnum species (S. palustre, S. subsecundum) being red-listed in Serbia, also the above mentioned species of the European Union Habitats and Species Directives, Hamatocaulis vernicosus, and other rarities in the Balkans, such as Calliergon giganteum, Dicranum bonjeanii, Drepanocladus polygamus, Fissidens adianthoides, and Straminergon stramineum. Due to the high elevation of the plateau, boreal liverworts (DüLL 1983) rare in the Balkans also occur on acidic soils and serpentine rocks, including Lophozia excisa, L. incisa, L. obtusa, and Scapania praetervisa (reported for the first time from Serbia here). Also, moss species rare in the Balkans with subarctic, boreal character (DÜLL 1984, 1985) live on limestone rocks here, such as Bryum uliginosum, Isopterygiopsis pulchella, Plagiobryum zierii, Schistidium atrofuscum, and Tortella fragilis. Among the latter ones we can also mention Myurella sibirica found for the first time in Serbia. Other boreal (and European red-listed) species that were located on decaying wood, are also additions to the list from the plateau, exemplified by Lophozia ascendens and Buxbaumia viridis. Temperate zone species of Europe (DÜLL 1983, 1984) occurring on the Pešter plateau, and rare in the Balkans, include Riccia canaliculata (found for the first time in Serbia here) and Riccardia multifida (these are living along streams), and Syntrichia latifolia that was found on tree bark.

Acknowledgements - The project was supported by the scientific exchange program of the Hungarian Academy of Sciences and the Serbian Academy of Sciences and Arts. We are grateful to Wiebke Schröder and Ludwig Meinunger (Ludwigsstadt-Ebersdorf), and Sorin Ştefãnuț (Bucureşti) for their help in confirmation/identification of some problematic specimens.

\section{REFERENCES}

Alegro, A., PAPp, B., SZurdoki, E., ŠEgota, V., ŠAPIĆ, I. and Vukelić, J. (2014): Contributions to the bryophyte flora of Croatia III. National Park Plitvička jezera and some adjacent areas. - Studia bot. hung. 45: 49-65.

DiERSSEN, K. (2001): Distribution, ecological amplitude and phytosociological characterization of European bryophytes. - Bryophyt. biblioth. 56: 1-289.

Dragićević, S., Papp, B. and Erzberger, P. (2011): Distribution of Buxbaumia viridis (Moug. ex Lam. \& DC.) Brid. ex Moug. \& Nestl. (Bryophyta) in Montenegro. - Acta Bot. Croat. 71(2): 1-6. http://dx.doi.org/10.2478/v10184-011-0066-1 
DragićEvić, S., Veljić, M. and MARIN, P. (2008): New records to the moss flora of Montenegro. - Cryptogamie, Bryol. 29(4): 397-400.

DülL, R. (1983): Distribution of the European and Macaronesian liverworts (Hepaticophytina). - Bryol. Beiträge 2: 1-115.

DÜLL, R. (1984): Distribution of the European and Macaronesian mosses (Bryophytina) I. - Bryol. Beiträge 4: 1-109.

DüLL, R. (1985): Distribution of the European and Macaronesian mosses (Bryophytina) II. Bryol. Beiträge 5: 110-232.

ECCB (1995): Red data book of European bryophytes. - European Committee for Conservation of Bryophytes, Trondheim, $291 \mathrm{pp}$.

Erzberger, P. and PApp, B. (2011): Schistidium dupretii (Thér.) W. A. Weber [Serbia]. In: Ellis, L. T. (ed.): New national and regional bryophyte records, 27. - J. Bryol. 33(2): 161. http://dx. doi.org/10.1179/1743282011Y.0000000007

Grims, F. (1999): Rote Liste gefährdeter Laubmoose (Musci) Österreichs. 2. Fassung. - In: Ni KLfELd, H. (ed.): Rote Listen gefährdeter Pflanzen Österreichs. Grüne Reihe des Bundesministeriums für Umwelt, Jugend und Familie, Wien, pp. 157-171.

Grolle, R. and Long, D. G. (2000): An annotated check-list of the Hepaticae and Anthocerotae of Europe and Macaronesia. - J. Bryol. 22: 103-140. http://dx.doi.org/10.1179/jbr.2000.22.2.103

Hill, M. O., Bell, N., Bruggeman-Nannenga, M. A., Brugués, M., Cano, M. J., Enroth, J., Flatberg, K. I., Frahm, J.-P., Gallego, M. T., Garilleti, R., Guerra, J., Hedenäs, L., Holyoak, D. T., Hyvönen, J., Ignatov, M. S., Lara, F., Mazimpaka, V., Muñoz, J. and SÖderström, L. (2006): An annotated checklist of the mosses of Europe and Macaronesia. - J. Bryol. 28(3): 198-267. http://dx.doi.org/10.1179/174328206X119998

Kopersin, M., Sauer, M., Braun, W. and Gradstein, S. R. (2000): Referenzliste der Moose Deutschlands. - Schriftenreihe f. Vegetationsk. 34: 1-519.

KubINSKÁ, A., JANOvicovÁ, K. and Šoltés, R. (2001): Updated checklist of liverworts, hornworts and mosses of Slovakia. - Bryonora 28: 4-10.

Natcheva, R., Ganeva, A. and Spiridonos, G. (2006): Red list of the bryophytes in Bulgaria. Phytol. Balcan. 12(1): 55-62.

Pantović, J., Grdović, S., Sabovljević, A. and Sabovljević, M. (2014): New and interesting bryophyte records for the flora of Serbia. - Arch. Biol. Sci., Belgrade, 66(2): 701-704. http://dx.doi.org/10.2298/ABS1402701P

PAPp, B. and ERzBerger, P. (2009): Contributions to the bryophyte flora of southeastern Serbia: Suva Planina Mts and its surroundings. - Studia bot. hung. 40: 125-142.

PApp, B. and Erzberger, P. (2010): Contribution to the bryophyte flora of Durmitor National Park, Montenegro. - Beih. Nova Hedwigia 138: 145-161.

PAPp, B. and ERzBerger, P. (2012): Contribution to the bryophyte flora of the Former Yugoslav Republic of Macedonia (FYROM). - Polish Bot. Journal 57(1): 205-221.

PAPp, B., Dragićević, S. and ERzBerger, P. (2014d): Contributions to the bryophyte flora of the Komovi Mts (Montenegro). - Studia bot. hung. 45: 17-31.

Papp, B., Erzberger, P. and Dragićević, S. (2013b): Contribution to the bryophyte flora of Bjelasica Mts (Montenegro). - Polish Bot. J. 58(1): 293-318. http://dx.doi.org/10.2478/pbj-2013-0030

Papp, B., Erzberger, P. and MARKa, J. (2010): Contributions to the bryophyte flora of eastern Albania (Korça and Kolonja districts). - Studia bot. hung. 41: 61-88.

PAPP, B., ERZBERGER, P. and SABOVLJEVIĆ, M. (2009): European red-listed bryophyte species collected during the expeditions of the Hungarian Natural History Museum in Serbia between 20002006. - In: Ivanova, D. (ed.): Plant, fungal and habitat diversity investigation and conser- 
vation. Proceedings of IV Balkan Botanical Congress, Sofia, 20-26 June 2006, Institute of Botany, Sofia, pp. 541-546.

PAPp, B., ERzBerger, P. and Tsakiri, E. (2011): Contributions to the bryophyte flora of Voras (Nidže) Mts (Greece and the Former Yugoslav Republic of Macedonia). - Studia bot. hung. 42: 51-76.

Papp, B., Szurdoki, E. and Sabovljević, M. (2012a): Grimmia incurva Schwägr. [Serbia]. In: ELLIS, L. T. (ed.): New national and regional bryophyte records, 30. - J. Bryol. 34(1): 46. http://dx.doi.org/10.1179/1743282011Y.0000000042

Papp, B., Szurdoki, E. and Sabovljević, M. (2012b): Ditrichum lineare (Sw.) Lindb. [Serbia]. In: ElLIS, L. T. (ed.): New national and regional bryophyte records, 33. - J. Bryol. 34(4): 283. http://dx.doi.org/10.1179/1743282012Y.0000000030

Papp, B., Szurdoki, E. and SAbovljević, M. (2012d): Bryophyte flora of Lake Vlasina and its surroundings (SE Serbia). - Studia bot. hung. 43: 27-45.

Papp, B., Szurdoki, E. and Sabovljević, M. (2014c): Bryum canariense (Brid.) Bruch \& Schimp. [Serbia]. In: Ellis, L. T. (ed.): New national and regional bryophyte records, 40. - J. Bryol. 36(3): 224. http://dx.doi.org/10.1179/1743282014Y.0000000115

Papp, B., Natcheva, R., Erzberger, P. and Sabovljević, M. (2012c): Didymodon sicculus, new to Bulgaria, Serbia and some notes on its ecology. - Nova Hedwigia 95(1-2): 221-226. http://dx.doi.org/10.1127/0029-5035/2012/0039

Papp, B., Pantović, J., Sabovljević, M. and Szurdoki, E. (2014a): Myurella sibirica (Müll. Hal.) Reimers, a moss species new to Montenegro and Serbia: its range extension towards south-eastern Europe. - Cryptogamie, Bryol. 35(3): 321-326.

Papp, B., Pantović, J., Sabovljević, M. and Szurdoki, E. (2014b): Interesting and new species for the bryophyte flora of Serbia. - Herzogia 27(1): 221-225.

Papp, B., Szurdoki, E., Pantović, J. and Sabovljević, M. (2013a): Physcomitrium eurystomum and Pohlia proligera, new mosses in the bryophyte flora of Serbia. - Arch. Biol. Sci., Belgrade, 65(2): 703-706. http://dx.doi.org/10.2298/ABS1302703P

PAPp, B., Alegro, A., ŠEgota, V., ŠAPIĆ, I. and Vukelić, J. (2013c): Contributions to the bryophyte flora of Croatia I. Gorski kotar Region (W Croatia). - Studia bot. hung. 44: 193-211.

Papp, B., Alegro, A., ŠEgota, V., ŠApić, I. and Vukelić, J. (2013d): Contributions to the bryophyte flora of Croatia II. The Northern Velebit. - Studia bot. hung. 44: 213-228.

Ros, R. M., Mazimpaka, V., Abou-Salama, U., Aleffi, M., Blockeel, T. L., Brugués, M., Cano, M. J., Cros, R. M., Dia, M. G., Dirkse, G. M., El-SaAdawi, W., ErdaĞ, A., Ganeva, A., González-Mancebo, J. M., Herrnstadt, I., Khalil, K., Kürschner, H., Lanfranco, E., Losada-Lima, A., Refai, M. S., Rodríguez-Nuñez, S., Sabovljević, M., Sérgio, C., Shabbara, H., Sim-Sim, M. and Söderström, L. (2007): Hepatics and Anthocerotes of the Mediterranean, an annotated checklist. - Cryptogamie, Bryol. 28(4): 351-437.

Ros, R. M., Mazimpaka, V., Abou-Salama, U., Aleffi, M., Blockeel, T. L., Brugués, M., Cros, R. M., Dia, M. G., Dirkse, G. M., Draper, I., El-SaAdawi, W., ErdaĞ, A., Ganeva, A., Gabriel, R., González-Mancebo, J. M., Granger, C., Herrnstadt, I., Hugonnot, V., Khalil, K., KÜrschner, H., Losada-Lima, A., Luís, L., Mifsud, S., Privitera, M., Puglisi, M., Sabovljević, M., Sérgio, C., Shabbara, H. M., Sim-Sim, M., Sotiaux, A., Tacchi, R., Vanderpoorten, A. and Werner, O. (2013): Mosses of the Mediterranean, an annotated checklist. - Cryptogamie, Bryol. 34(2): 99-283. http://dx.doi.org/doi/10.782/cryb.v34.iss2.2013.99

SABOvLJEVIĆ, M. (2000): Checklist of hepatics of the Federal Republic of Yugoslavia. - Lindbergia 25: $37-42$. 
Sabovljević, M. and Natcheva, R. (2006): A check-list of the liverworts and hornworts of Southeast Europe. - Phytol. Balcan. 12: 169-180.

Sabovljević, M. and SteVAnović, V. (1999): Moss conspectus of Federal Republic of Yugoslavia. - Flora Medit. 9: 65-95.

SABovljević, M., PAPp, B. and Szurdoki, E. (2010): New bryophyte records to some countries of the South-Eastern Europe. - Cryptogamie, Bryol. 31(3): 289-292.

Sabovljević, M., Cvetić, T. and Stevanović, V. (2004): Bryophyte red list of Serbia and Montenegro. - Biodiversity and Conservation 13: 1781-1790.

http://dx.doi.org/10.1023/B:BIOC.0000029338.97776.66

Sabovljević, M., Natcheva, R., Tsakiri, E., Dihoru, G., Dragićević, S., ErdaĞ, A. and PAPP, B. (2008): Check-list of the mosses of SE Europe. - Phytol. Balcan. 14: 207-244.

SEKULIĆ, N. and ŠINŽAR-SEKULIĆ, J. (2010): Emerald ecological network in Serbia. - Institute for Nature Conservation of Serbia, Belgrade, 100 pp.

Sмit H, A. J. E. (2004): The moss flora of Britain and Ireland. - University Press, Cambridge, 739 pp. ŞTEFĂNUȚ, S. and GoiA, I. (2012): Checklist and red list of the bryophytes of Romania. - Nova Hedwigia 95(1-2): 59-104. http://dx.doi.org/10.1127/0029-5035/2012/0044 